\title{
The construction of a growth-oriented global climate agenda: a critical historical analysis
}

\author{
La construcción de una agenda climática global pro-crecimiento: \\ un análisis histórico crítico
}

\author{
Cati Torres ${ }^{1^{*}}$ (i) \\ Joan Moranta ${ }^{2}$ (D) \\ Ivan Murray ${ }^{3}$
}

\begin{abstract}
By the end of 2019, more than 11,000 world scientists declared Planet Earth is facing a climate emergency, which signals the failure of the global climate agenda (GCA). Since it took off thirty years ago, emissions have continued to increase at the planetary level. We add to the literature focusing on the economic and political dimensions shaping the GCA. In particular, we examine its economic growth roots under the umbrella of sustainable development (SD) or green growth to shed some light on whether the rules driving the world economy are shaping it. Such rules are built on the growth ideology fuelling the current extractivist socioeconomic metabolism, which in turn lies behind the socioecological crisis. We review the main international climate-focused events and document a shift in the guiding principles of climate politics from the 1980s onwards under which growth is no longer viewed as a driver of climate change (CC) but as its solution. We argue that the strategy to promote growth-based SD represents the main cause of policy failure. Indeed, the result is a policy that is highly reliant on technological solutions and market-based instruments and leads to the belief that green growth is both possible and the solution to CC. Such a belief restricts the debate to the economy's 'decarbonisation' and CC adaptation and overlooks other important socio-political aspects involve in climate action.
\end{abstract}

Keywords: Greenhouse gases; climate change; climate governance; technological solutions; green growth; sustainable development.

\section{Resumen}

A finales de 2019, más de 11.000 científicos declararon que afrontamos una emergencia climática que obliga a actuar con urgencia, lo que muestra el fracaso de la agenda climática global (ACG). Desde sus inicios hace treinta años, no se ha revertido la tendencia creciente de las emisiones globales. Este artículo contribuye al debate existente en torno al análisis de la influencia de factores económicos y políticos sobre el diseño de ACG examinando su objetivo de crecimiento económico. Buscamos aclarar si las reglas del juego económico mundial, sustentadas en la ideología del crecimiento, impulsora del actual metabolismo socioeconómico extractivista que subyace a la crisis socioecológica planetaria, determinan dicha agenda. Así, revisamos los principales eventos internacionales en torno al cambio climático (CC) y documentamos un giro en los principios de la política climática a partir de los años ochenta del siglo pasado, según el cual el crecimiento dejó de verse como la causa del CC para verse como su solución.

1 Applied Economics Department, Universitat de les Illes Balears, Spain. cati.torres@uib.cat. *Corresponding author.

2 Instituto Español de Oceanografía (IEO, CSIC), Centre Oceanogràfic de Balears (COB), Ecosystem Oceanography Group (GRECO), Spain.joan.moranta@ieo.es

3 Department of Geography, Universitat de les Illes Balears, Spain. vivan.murray@uib.cat 
Argumentamos que el hecho de promover un desarrollo sostenible basado en el crecimiento explica el fracaso de la política climática. Y es que esto resulta en una política demasiado optimista hacia las soluciones tecnológicas y los instrumentos de mercado que lleva a creer que el crecimiento verde es posible y la solución al CC, lo que limita la acción a la "descarbonización" de la economía y la adaptación al CC ignorando otros aspectos sociopolíticos relevantes.

Palabras clave: Gases de efecto invernadero; cambio climático; gobernanza climática; soluciones tecnológicas; crecimiento verde; desarrollo sostenible.

\section{Introduction}

Anthropogenic climate change (CC) is one of the world's biggest ecological challenges (Ash et al., 2013; McNutt, 2013; Romero \& Olcina, 2021). Since the Study of Critical Environmental Problems conference held half a century ago, many scientists have warned about the serious consequences of CC and their cumulative impacts on ecosystems and their dependent human systems (Gil \& Olcina, 2021; Ripple et al., 2017). Higher temperatures, eutrophication, ocean acidification, lower precipitation rates, sea-level rise or more frequent and intense extreme events among others are expected to affect terrestrial and aquatic ecosystems as well as water and energy facilities, infrastructures, human health, the economy, and human rights and social justice (IPCC, 2014, 2018; Martín \& Gallego, 2010).

To face this challenge, a global climate agenda (GCA) was initiated with the creation of the Intergovernmental Panel on Climate Change (IPCC) in 1988 and the UN Framework Convention on Climate Change (UNFCCC) in 1992. However, the political commitments derived from the UNFCCC-related international agreements have not changed greenhouse gas (GHG) emissions trends and global emissions have continued to increase (Kuyper, Schroeder, \& Linnér, 2018; Wamsler et al., 2020). From 2000 to 2010, emissions grew on average by $2.2 \%$ per year almost doubling the mean annual growth rate for the 1970-2000 period (IPCC 2014). Friedlingstein et al. (2020) show total $\mathrm{CO}_{2}$ emissions passed from an annual mean of $4.5 \mathrm{GtCyr}^{-1}$ for the decade of the 1960s to one of $10.9 \mathrm{GtCyr}^{-1}$ during 2010-2019, thus increasing by $142.2 \%$. Emission trends have only been interrupted during global economy collapses such as the aftermath of World War II, the oil crisis of the late 1970s or the 2008 financial crash. The dramatic $8.8 \%$ fall in global $\mathrm{CO}_{2}$ emissions in the first half of 2020 (compared to the same 2019 period) due to the COVID-19 pandemic (Liu, Ciais, Deng, $\&$ Al., 2020) is the latest example. Nevertheless, this drop is likely to be temporary as it does not reflect structural economic, transport or energy systems changes (Le Quéré et al., 2020).

Evidence shows the international CC mitigation efforts made during the last thirty years have not been sufficient, thus signalling the failure of global climate policies (Stevenson, 2021; Stevenson \& Dryzek, 2013). Most of the advanced capitalist countries who ratified the 1997 Kyoto Protocol failed to meet their 2012 emission reduction targets which were after all only to make a very small difference to the global GHG concentration trends (Dryzek, Norgaard, \& Scholsberg, 2013; Helm, 2008). The outcome of the 2009 Copenhagen Conference was a last-minute Accord negotiated by the US and China resulting in loose commitments on both targets and funding which were endangered by countries' disagreements on responsibilities' distribution (Bailey, 2017; Dryzek et al., 2013). The 2012 Doha Amendment adopted for the Kyoto Protocol's 2013-2020 commitment period has not yet entered into force. The link between the Paris goals and the nationally determined contributions (NDC) is not well defined in the Paris Agreement either, thus resulting in the NDCs being insufficient to achieve the Agreement's objectives (Kuyper et al., 2018). Nieto et al. (2018) estimate that, in the best of cases, this Agreement will lead to an increase in annual world emissions by approximately $19.3 \%$ in 2030 for the $2005-2015$ period, resulting in a global temperature rise of at least $3^{\circ} \mathrm{C}$ minimum. At the 2018 Kattowice Conference, no agreement on the development of voluntary market-based mechanisms was reached moving this decision into the 2019 Santiago Conference (finally held in Madrid). However, the Madrid outcomes were not promising either as developed countries were reluctant to undertake ambitious climate action and had yet to enhance support to developing countries in finance technology and capacity.

The question of why has so little been achieved within the global CC frameworks and agreements is an issue of ongoing concern within the literature. The complex nature of CC, the difficulty to bring on board aviation and shipping, the focus on carbon production (rather than consumption), the voluntary nature of agreements, the free-rider problem, the lack of willingness by governments to compromise national interests (or by markets to solve the problem), the increased participation of non-state actors under a consensus-based system, the doubtful UNFCCC's ability to deliver a truly inclusive and deliberative 
space, and high future discounting have been said to be important policy failure's contributors (Bailey, 2017; Gupta, 2010; Helm, 2008; Kuyper et al., 2018). With a focus on the Paris Agreement, potential reasons for a lack of action go beyond the fact NDCs are not legally binding (Kuyper et al., 2018) and include i) the non-existence of any control, monitoring and penalization system; ii) the low quality and scarce clarity of the provided information; iii) the need of a high amount of external funding for low developed countries to comply with NDCs; and iv) the fact all funding has to be channelled through individual projects, carbon markets and the private initiative (Nieto, Carpintero, \& Miguel, 2018).

More critically, some works have referred to the economic and political dimensions shaping the architecture of climate policy as drivers of its failure, thus calling for a change of the current socioeconomic system to ensure action's effectiveness. This system has been said to be governed by "an elite minority that has a stranglehold over the economy, the political process and most of the major media outlets" (Klein, 2014), consequently, allowing it to define the rules of the world economy. As stated by Ciplet and Roberts (2017), the contemporary UNFCCC regime has institutionalized neoliberal reforms in climate governance. Changing the current socioeconomic order would involve changing these rules as they grant privileges to the wealthiest, as long stated by critical researchers, independent organisations and individuals and social movements (Arrighi, 2009; Malm, 2016; Newell, 2012). Accordingly, many authors claim there is a need to replace the dominant societal objectives and to shift the balance of political-cultural power in society to ensure a real path toward sustainability (Bailey, 2017; Foster \& Clark, 2012; Klein, 2020; O'Brien, 2017; Pelling, 2011). This raises an interesting question: are the rules driving the world economy shaping the actual climate policy? In other words, are the weaknesses of the actual climate policy architecture responding to the interest of the powerful to keep the status quo? The difficulties to effectively reach the committed emission targets due to the flexible architecture of a climate policy subject to the Global North's plans seem to insinuate an affirmative response.

To shed some light on the ongoing GCA, this paper examines its growth roots under the umbrella of sustainable development (SD) or green growth. The rules driving the world economy build on the economic growth ideology which feeds a socioeconomic metabolism (or the sum total of material and energy flows between nature and society) being highly dependent on accelerated, intense extractive activities and hence responsible for the actual planetary socioecological crisis (Boulding, 1966; Haberl et al., 2019; Krausmann, Lauk, Haas, \& Wiedenhofer, 2018; Pauliuk \& Hertwich, 2015; Schandl et al., 2018). In a context of climate emergency where evidence shows a clear positive correlation between global GDP and emissions (Kallis et al., 2018), this paper pursues to critically analyze climate policy due to its promotion of a green economy (Moreno et al., 2016). To this end, the paper has been structured as follows. In the next section, we describe the methodology used to examine the vision of the main climate-focused events on the relationship between growth and CC. We make a critical historical analysis of such events from a political ecology perspective rather than a physical one. In section 3, we present the results of such analysis and discuss them in section 4, where we explore the defining elements of a growth-oriented climate policy and reflect on why pursuing growth becomes a non-sensical and reckless strategy to fight against CC. A Conclusions section ends the paper.

\section{Methodology}

To draw conclusions about whether the rules driving the world economy are shaping the GCA, we proceeded as follows. At a first stage, we made use of all of the available sources in order to familiarize ourselves with the construction of the GCA. Among others, this task involved reviewing literature on both climate science/policy and environmental/sustainability issues; consulting reports and proceedings of climate/environmental conferences held post II World War; reading up on the world central governance institutions (e.g. mission, objectives, publications, policy recommendations) as well as finding out about the potential role played by major political leaders in the GCA construction. Secondly, we selected the climate-focused events we considered to be more representative to explain the development of climate politics. Table 1 reports a chronology of such events together with the international events focusing on economic/ecological issues characterizing the political-historical context where the climate-focused events took place which we considered have played a role in the GCA construction. Finally, we analyzed the vision of the selected climate-focused events on the relationship between growth and CC. Specifically, we examined the way they understand CC and their accordingly derived climate policy recommendations, as outlined in the following sections. 
Table 1. Chronology of the main international events involved in the construction of climate governance since the II World War

\begin{tabular}{|c|c|c|}
\hline YEAR & MAIN INTERNATIONAL EVENTS & $\begin{array}{l}\text { CLIMATE- } \\
\text { FOCUSED }\end{array}$ \\
\hline 1955 & 1. "Man's Role in Changing the Face of the Earth" Symposium (MRCFE) & \\
\hline 1965 & 2. Causes on Climate Change Conference (Boulder conference) & $\mathrm{X}$ \\
\hline 1970 & 3. Study of Critical Environmental Problems Conference (SCEP) & $\mathrm{X}$ \\
\hline 1971 & 4. Study of Man's Impact on Climate Conference (SMIC) & $\mathrm{X}$ \\
\hline 1972 & $\begin{array}{l}\text { 5. "Limits to Growth" Report (Meadows Report) } \\
\text { 6. UN Conference on the Human Environment (Stockholm Conference) }\end{array}$ & \\
\hline 1974 & 7. Cocoyoc Symposium & \\
\hline 1979 & $\begin{array}{l}\text { 8. First World Climate Conference (WCC-1) } \\
\text { 9. Election victory of Thatcher (1979), who played a determined stand on CC, marking the } \\
\text { beginning of the global "neoliberal" era. }\end{array}$ & $\begin{array}{l}\mathrm{X} \\
\mathrm{X}\end{array}$ \\
\hline 1983 & 10. Creation of the World Commission on Environment and Development (WCED) & \\
\hline 1986 & 11. Beginning of Uruguay Round of Multilateral Trade Negotiations & \\
\hline 1987 & $\begin{array}{l}\text { 12."Our Common Future" Report (Brundtland Report) } \\
\text { 13."Earth as Transformed by Human Action" Symposium }\end{array}$ & \\
\hline 1988 & $\begin{array}{l}\text { 14. World Conference on the Changing Atmosphere (Toronto Conference) } \\
\text { 15. Intergovernmental Panel on Climate Change (IPCC) }\end{array}$ & $\begin{array}{l}\mathrm{X} \\
\mathrm{X}\end{array}$ \\
\hline 1990 & $\begin{array}{l}\text { 16. First IPCC Assessment Report } \\
\text { 17. Second World Climate Conference (WCC-2) }\end{array}$ & $\begin{array}{l}\mathrm{X} \\
\mathrm{X}\end{array}$ \\
\hline 1992 & $\begin{array}{l}\text { 18. UN World Conference on Sustainable Development (Rio/ Earth Summit) } \\
\text { 19. UN Framework Convention on Climate Change (UNFCCC) }\end{array}$ & $\mathrm{X}$ \\
\hline 1994 & $\begin{array}{l}\text { 20. Signature of Marrakesh Agreement } \\
\text { 21. End of Uruguay Round of Multilateral Trade Negotiations }\end{array}$ & \\
\hline 1995 & $\begin{array}{l}\text { 22. Creation of the World Trade Organization (WTO) } \\
\text { 23. Beginning of UNFCCC Conferences of the Parties with the Berlin Conference (COP-1) - Berlin } \\
\text { Mandate }\end{array}$ & $\mathrm{X}$ \\
\hline 1996 & 24. Second IPCC Assessment Report & $\mathrm{X}$ \\
\hline 1997 & 25. UNFCCC Kyoto Conference (COP-3) - Kyoto Protocol & $\mathrm{X}$ \\
\hline 2001 & 26. Third IPCC Assessment Report & $\mathrm{X}$ \\
\hline 2002 & 27. UN World Summit on Sustainable Development (Johannesburg Summit) & \\
\hline 2005 & $\begin{array}{l}\text { 28. Coming into force of the Kyoto Protocol with Russia's ratification. } \\
\text { 29. Commemoration of the } 50^{\mathrm{th}} \text { anniversary of the "Man's Role in Changing the Face of the Earth" } \\
\text { Symposium }\end{array}$ & $\mathrm{X}$ \\
\hline 2007 & 30. Fourth IPCC Assessment Report & $\mathrm{X}$ \\
\hline 2009 & $\begin{array}{l}\text { 31. Third World Climate Conference (WCC-3) } \\
\text { 32. UNFCCC Copenhagen Conference (COP-15) - Copenhagen Accord }\end{array}$ & $\begin{array}{l}\mathrm{X} \\
\mathrm{X}\end{array}$ \\
\hline 2011 & 33. UNFCCC Durban Conference (COP-17) & $\mathrm{X}$ \\
\hline 2012 & $\begin{array}{l}\text { 34. UN Conference on Sustainable Development (Rio 2012/Rio+20/2012 Earth Summit) } \\
\text { 35. UNFCCC Doha Conference (COP-18) - Doha Amendment }\end{array}$ & $\mathrm{X}$ \\
\hline 2014 & 36. Fifth IPCC Assessment Report & $\mathrm{X}$ \\
\hline 2015 & $\begin{array}{l}\text { 37. Adoption of the } 2030 \text { Agenda at the UN Sustainable Development Summit and hence its } 17 \\
\text { SDGs including Climate Action (13 SDG) } \\
\text { 38. UNFCCC Paris Conference (COP-21) - Paris Agreement }\end{array}$ & $\begin{array}{l}X \\
X\end{array}$ \\
\hline 2019 & $\begin{array}{l}\text { 39. IPCC "Global Warming of } 1.5^{\circ} \mathrm{C} \text { " Special Report } \\
\text { 40. IPCC "Refinement to the } 2006 \text { IPCC Guidelines for National GHG Inventories" Special Report }\end{array}$ & $\begin{array}{l}X \\
X\end{array}$ \\
\hline 2020 & $\begin{array}{l}\text { 41. US withdrawal from the Paris Agreement } \\
\text { 42. First European Climate Change Law } \\
\text { 43. European Climate Pact as part of the European Green Deal }\end{array}$ & $\begin{array}{l}X \\
X \\
X\end{array}$ \\
\hline 2021 & $\begin{array}{l}\text { 44. US return to the Paris Agreement } \\
\text { 45. UNFCCC Glasgow Conference (COP-26) (postponed in } 2020 \text { due to COVID-19) } \\
\text { 46. Working Group I Contribution to the Sixth IPCC Assessment Report (for the first global } \\
\text { stocktake in 2023): The Physical Science }\end{array}$ & $\begin{array}{l}X \\
X \\
X\end{array}$ \\
\hline 2022 & 47. Rest of Working Group Contributions to the Sixth IPCC Assessment Report ${ }^{*}$ & $\mathrm{X}$ \\
\hline
\end{tabular}

"Expected events. 


\subsection{Causes of Climate Change (The Boulder Conference)}

Held in 1965, the Boulder conference was the first scientific conference on the causes of CC. It took place at the time of a social public debate on the ecological impacts of economic growth. However, the high level of uncertainty regarding the anthropogenic influence on the atmosphere composition led scientists to consider the need for further research rather than calling for a reduction in the expansion of human activities. Indeed, the alteration of the atmosphere was considered a minor problem which did not justify reducing the exponential economic growth. Despite research highlighting the atmosphere's limited capacity, uncertainty around this capacity served to keep things equal (MacDonald, 1966).

\subsection{Study of Critical Environmental Problems (The SCEP Conference) and Study of Man's Impact on Climate (The SMIC Conference)}

The SCEP and SMIC conferences played a significant role in visualizing the CC problem. These conferences drew attention to $\mathrm{CC}$ as a global environmental conflict, thus fuelling concerns about the ecological consequences of the growth-driven expansion of human activities. The discovery of the oceans' limited capacity of carbon absorption (thought to explain the Keeling (1960)'s measured annual rise in anthropogenic $\mathrm{CO}_{2}$ concentration in the atmosphere), led for the first time US researchers to consider CC as a critical problem at the SCEP held in Massachussetts in 1970. Postponing policies due to scientific uncertainty was viewed unfeasible. Despite the low probability of $\mathrm{CO}_{2}$-induced $\mathrm{CC}$ in the $20^{\text {th }}$ century, long-term potential consequences of $\mathrm{CO}_{2}$ effects on the climate and of social reaction to such threats were considered serious, thus calling not only for further research but also for action (SCEP, 1970).

To assist the SCEP requests on climate, the SMIC was held in Stockholm in 1971 bringing together scientists from all over the world. It advocated the interrelated nature of atmospheric processes and presented CC as a critical problem in an international context of increased concern about the growth-derived ecological effects. The SMIC discussed the many ways human activities including the addition of fossil fuel burning-derived $\mathrm{CO}_{2}$ might affect global atmospheric processes (SMIC, 1971). That conference recognized that climate could change dangerously and stated special attention should be paid to emissions of particle pollutants and GHGs (Wilson \& Matthews, 1971). Though the expected magnitude of CC impacts was still uncertain (Hammond, 1972), the SMIC concluded CC was a real threat and acknowledged mankind's power to change the global climate (Kellogg, 1987).

\subsection{First World Climate Conference (WCC-1)}

Held in Geneva in 1979 under the theme "A Conference of Experts on Climate and Mankind", the WCC-1 also emphasized the interrelated nature of atmospheric processes and expressed increased concerns about the growth-derived ecological effects. It recommended preserving soil fertility, promoting the efficient use of water resources, forests and rangelands, ceasing desertification, and reducing atmospheric and ocean pollution to reverse ecological degradation (WMO, 1979). It pointed out that the continued expansion of human activities could cause important regional and global climate changes which could become significant before the middle of the $21^{\text {st }}$ century. It opened the door to redirect the world economy to ensure the coevolution of nature and society and hence mankind's long-term survival (WMO, 1979).

The WCC-1 also called for a World Climate Programme (WCP). This would act as an authoritative international scientific scheme to improve understanding of the climate system so that societies could better cope with climate variability and change. WCP specifically pursued strategies to assist countries in making better use of climate information in planning for social and economic development (WMO, 1979).

\subsection{World Conference on the Changing Atmosphere: Implications for Global Security (The Toronto Conference)}

The Toronto Conference was held in 1988 and focused on the changing atmosphere due to the continued growth in fossil fuel burning-derived atmospheric concentrations of $\mathrm{CO}_{2}$ and other gases (WMO, 1988). Driven by Brundtland-based SD principles ${ }^{4}$, it viewed CC as a problem of pollutants, burning of fossil

\footnotetext{
4 Gro Harlem Brundtland gave the Keynote Address of the conference, which strongly supported the proposal for a 1992 World Conference on Sustainable Development under the UN auspices (WMO, 1988).
} 
fuels and poverty and for the first time called on the world's governments to set strict, specific targets for reducing GHG emissions (Weart, 2008). It also called for using conventional economic tools for internalizing energy external costs and providing incentives to developing countries to sustainably manage their tropical forest resources. Energy options for development and the environment were recommended. Setting targets for energy efficiency improvements and energy supply, as well as switching to lower $\mathrm{CO}_{2}$ emitting fuels and implementing renewable energy were emphasized. Revisiting the nuclear power option was also suggested under the belief that better engineering designs and institutional arrangements could solve problems related to nuclear safety, radioactive wastes, and nuclear weapons proliferation (WMO, 1988).

The conference also called for increased research funding and monitoring efforts within the WCP, support for the IPCC creation and development of a comprehensive global convention as a framework for protocols on the atmosphere protection (Zillman, 2009).

\section{5. "Climate activism" of Margaret Thatcher}

The interest in defeating the UK coal mining trade unions (Fontana, 2018; Milne, 2014) led Margaret Thatcher to opportunistically hoist the climate activism's sign. While closing coal mines and weakening miners' unions in the country, she was initiating intensive oil and gas drilling projects in the North Sea, trying to reactivate the nuclear power and arms sectors and started to import coal from the rest of the world (Fernández-Durán, 2010). At the time she initiated a "Thatcherism" process fed by radical capitalist free trade ideas (Edgerton, 2018), she became the first major political leader to take a determined stand on CC and invest new funds in related research (Weart, 2008). She played an active role in establishing a GCA built on the Brundtland report-based SD principles which she defended at the Toronto conference (WMO, 1988), her 1988 foreword to "Our Common Future" and her speeches to both the Royal Society in 1988 and the UN General Assembly in 19895.

Accordingly, she promoted the creation of the IPCC in 1988 which also received support by the conservatives and CC sceptics in the US administration which aimed to tame climate politics. They thought it would be easier to control an IPCC created under the UN scheme, which would lead to more moderate statements, than independent scientists and their structures (Weart, 2008). Besides, they considered having a UN body for assessing CC related science would convert the work of IPCC into the official and soundest CC knowledge this serving as a way of silencing critical voices of environmental NGOs and scholars (Hulme, 2020). By continuously stressing the need for further scientific research, climate action could be easily postponed this ensuring the expansion of global capitalism.

Thatcher was also one of the few political leaders attending the 1990 II World Climate Conference. However, concerned about the anti-capitalist arguments which the campaigners against global warming were deploying, she later abandoned the CC cause and then her arguments that growth had to be environmentally sustainable (Thatcher, 2002).

\subsection{Intergovernmental Panel on Climate Change (IPCC)}

As the UN body for assessing CC science, the IPCC provides governments with information about $\mathrm{CC}$, its impacts and future risks, as well as socieconomic advice about adaptation and mitigation. Since its creation, it has delivered five Assessment Reports representing the most comprehensive scientific CC reports produced worldwide and a range of Methodology Reports, Special Reports and Technical Papers in response to requests for information on specific scientific and technical matters from the UNFCCC, governments and international organizations.

Despite being the authoritative source of CC knowledge (Zillman, 2009), the hybrid nature of the members of the IPCC (consisting of government representatives and scientists) has led to some controversies around its work. Disputes have been said to normally involve its economic and policy aspects rather than its scientific results which although having to be negotiated are considered quite robust (Helm, 2008). However, some authors state the IPCC's consensus approach leads to the underexposure not only of political but also of scientific dissent, this leading to the politicization of climate science (van der Sluijs, van Est, \& Riphagen, 2010).

5 Documents 107302, 107306 and 107817, respectively, available on https://www.margaretthatcher.org/document/. 


\subsection{Second World Climate Conference (WCC-2)}

Held in Geneva in 1990, the first purpose of WCC-2 was to review the WCP including major achievements in the application of climate information to food, water, energy and urban and building design challenges. Its second purpose was to undertake a review of the IPCC First Assessment Report as a leading to the UNFCCC negotiations (Zillman, 2009). It stressed the need for further scientific research mainly by supporting the WCP and recommended the urgent development of a Global Climate Observing System, thus being a relevant call for international cooperation (Zillman, 2009). The historical emissions growth was viewed as a direct consequence of fossil fuel burning by advanced capitalist societies together with an increase of human population, rising incomes, and the expansion of agriculture. The conference concluded improving energy use efficiency and employing alternative fuels/energy sources was technically feasible and cost-effective to reduce $\mathrm{CO}_{2}$ emissions, which would allow many capitalist regions to stabilize their emissions from the energy sector (WMO, 1990).

Climate information was considered as a relevant tool to assist SD which was recognized to be threatened by CC. Research, development, co-development and technology transfer regarding energy efficiency and non-fossil fuel energy technologies were viewed as important not only to reduce emissions but also to move to more SD pathways (WMO, 1990).

\subsection{The United Nations Framework Convention on Climate Change (UNFCCC)}

Supported by the IPCC work (Le Treut et al., 2007), the UNFCCC is the key international treaty to reduce global warming and cope with CC impacts. New agreements of overall targets and GHG emission allocation are negotiated in the annual two-week Conference of the Parties (COP) (Dryzek et al., 2013). It was signed at the 1992 UN Conference on Environment and Development which was a milestone for environmental sustainability and SD. It entered into force in 1994, a period of international trade liberalization driving both the "neoliberal" globalization process and the increase of global GHG emissions (Dorninger et al., 2021). It became operational before the signature of the Marrakesh Agreement which both marked the end of the Uruguay Round of Multilateral Trade Negotiations (1986-1994) and established the World Trade Organization (WTO). Responding to an international context which enshrined economic growth as necessary for development, all the UNFCCC-derived global agreements are growth-oriented. Indeed, the UNFCCC ultimate goal (Art. 2) is to stabilize GHG concentrations in the atmosphere to prevent dangerous anthropogenic CC in such a way that enables sustainable economic development. The fact countries are forced to comply with the WTO decisions while they can voluntarly decide if complying or not with those taken by the UNFCCC shows the priority given to growth by the current central climate governance institutions (Zelli \& van Asselt, 2010).

The Berlin Mandate resulting from the first 1995 COP pointed to the responsibility of advanced capitalist countries to reduce GHGs and formed the starting point for the negotiations toward the Kyoto Protocol.

\subsection{Kyoto Protocol (COP-3)}

To make operational the UNFCCC, the Kyoto Protocol was adopted in 1997. With a focus on countries roles in emitting fossil fuel burning-derived GHGs to the atmosphere, the protocol placed a heavier burden on Annex I countries under the principle of "common but differentiated responsibility and respective capabilities". Annex I countries were some capitalist countries (mostly from the Global North), economies in transition and the EU. The protocol aimed to reduce Annex I country emissions by an average of 5\% from 1990 levels over the 2008-2012 first commitment period (UNFCCC, 1997). Inspired by the SD narrative, it emphasized the need to correct for the CC market failure and invest in technological solutions. It recommended using market-based environmental policy tools (emissions trading, Clean Development Mechanism, Joint Implementation), enhancing energy efficiency and investing in renewable energy sources as well as in advanced and innovative technologies such as carbon sequestration (UNFCCC, 1997).

However, its architecture generated distributional conflicts at domestic and international levels leading among others to the US no ratification, thus coming into force in $2005^{6}$, the failure of the $2009 \mathrm{Co}-$ penhagen conference and the advanced capitalist countries' lower willingness to sign up to the Protocol's 2013-2020 second commitment period (Kuyper et al., 2018).

6 It was only operational when Europeans bargained the WTO membership and other concessions with Russia (Helm, 2008). 


\subsection{Third World Climate Conference (WCC-3)}

The WCC-3 was held in Geneva in 2009 under the theme "Climate Prediction and Information for Decision Making". It emphasised the need for both the best possible climate science and information, as well as their effective application through climate services and tools to better adapt to climate-related risks thus ensuring SD (WMO, 2009a). The WCC-3 cited the need for comprehensive climate information supporting national and international strategies to reduce emissions and adapting to unavoidable CC (Zillman 2009). This was influenced by the IPCC Third Assessment Report (2001), the Johannesburg World Summit on SD (2002) and the growing recognition that the global CC challenge should be addressed through a mitigation/adaptation balance. The development and implementation of the Global Framework for Climate Services was also supported (WMO, 2009b).

At the WCC-3, information was assigned an economically and socially important role in developing new climate commodification and financial mechanisms to function as socioecological fixes to the 2008 financial crash (McCarthy, 2015). Information was said to be relevant to achieve sustainable energy based on more efficient production and use of traditional non-renewable energy forms, as well as on designing and operating renewable energy infrastructures and facilities (WMO, 2009a). Accurate carbon flows measurement was considered key to creating carbon markets. The WCC-3 recognized decoupling emission growth from development advances as possible, starting the basis for its contribution to the Millenium Development Goals (MDGs) for 2015 (WMO, 2009a) and the Paris Agreement (Kuyper et al., 2018).

\subsection{Paris Agreement (COP-21)}

The problems associated to the Kyoto Protocol led the 2011 Durban Conference to claim for the need to renegotiate a universal legal agreement no later than 2015, this resulting in the Paris Agreement entering into force in 2016. In the context of SD, the Agreement's objective is to strengthen the global response to the $\mathrm{CC}$ threat by keeping a planetary temperature rise well below $2^{\circ} \mathrm{C}$ in the $21^{\text {st }}$ century and pursue efforts both to limit it to $1.5^{\circ} \mathrm{C}$ and to eradicate poverty (UNFCCC, 2015).

The shift from Kyoto's targeting advanced capitalist country emissions to the requirement of intended NDCs by the Paris Agreement's signatories implicitly shows a watering down of the emissions reductions responsibility of rich countries. According to Kuyper et al. (2018), the interest in raising global ambition has led to a more flexible climate policy built on pledges of commitments and contributions with the participation of more nonstate and substate actors converting the UNFCCC into a coordinator rather than an implementer ${ }^{7}$. As a result of such a flexibilization process, adaptation and finance have become additional goals to mitigation (UNFCCC 2015), thus emphasizing the role of technological solutions to CC $^{8}$.

\section{Results}

Through the previous analysis we observe that the main climate-focused events involved in the construction of climate politics post II World War can be divided into two groups according to their vision on the relationship between growth and CC. Indeed, the reviewed events taking place before the 1980's view CC as another global environmental problem derived from the expansion of human activities motivated by the growth imperative. In contrast, the events being hold from the 1980's onwards advocate for a growth-based SD to solve for CC which is understood as the result of fossil fuel burning-derived GHGs in the atmosphere. In other words, we find out that climate politics before the 1980's understood growth as a driver of the planetary socioecological conflicts, while it considered growth as the solution to environmental problems and poverty from the 1980's onwards (Table 2). In line with Gómez-Baggethun $\&$ Naredo (2015), we document a shift in the guiding principles of climate politics from 1980s onwards when economic growth became a global political objective at the international governance level.

\footnotetext{
7 Despite such a flexibilization, CC denial by Donald Trump led him to announce the USA withdrawal from the Paris Agrement in June 2017, which was formalized in November 2020. However, the election victory by Joe Biden at the end of 2020 has led the USA to return to the Agreement in February 2021.

8 Ignored in early Kyoto Protocol negotiations, adaptation gained gradually importance especially since the publication of the Third Assessment Report (Kuyper et al., 2018).
} 
Table 2. Overview of the construction of a growth-oriented global climate agenda*

\begin{tabular}{|c|c|c|c|c|}
\hline \multicolumn{2}{|c|}{ VISION ON GROWTH } & \multicolumn{2}{|c|}{ MAIN INTERNATIONAL EVENTS } & \multirow[b]{2}{*}{$\begin{array}{l}\text { VISION ON CLIMATE } \\
\text { CHANGE (CC) }\end{array}$} \\
\hline International context & Vision & $\begin{array}{c}\text { Focused on } \\
\text { economic/ } \\
\text { ecological issues }\end{array}$ & $\begin{array}{l}\text { Focused on } \\
\text { climate }\end{array}$ & \\
\hline \multirow{2}{*}{$\begin{array}{l}\text { Global public debate on } \\
\text { limits to growth }\end{array}$} & \multirow{2}{*}{$\begin{array}{c}\text { Growth as a driver } \\
\text { of planet's ecological } \\
\text { unbalance }\end{array}$} & \multicolumn{2}{|c|}{ Years: 1955-1981 } & \multirow{2}{*}{$\begin{array}{l}\text { CC as another } \\
\text { growth-derived global } \\
\text { environmental problem }\end{array}$} \\
\hline & & $1,5,6,7$ & $2,3,4,8,9$ & \\
\hline \multirow[b]{2}{*}{$\begin{array}{l}\text { Growth-based } \\
\text { sustainable development } \\
\text { or green growth as a } \\
\text { global political goal }\end{array}$} & \multirow[b]{2}{*}{$\begin{array}{c}\text { Growth as the solution } \\
\text { to environmental } \\
\text { problems }\end{array}$} & \multicolumn{2}{|c|}{ Years: 1983-2019 } & \\
\hline & & $\begin{array}{c}10,11,12,13,18 \\
20,21,22,27 \\
29,34\end{array}$ & $\begin{array}{c}14,15,16,17,19 \\
23,24,25,26, \\
28,30,31,32,33 \\
35,36,37,38,39 \\
40,41,42,43,44 \\
45,46,47\end{array}$ & $\begin{array}{l}\text { CC as the result of fossil } \\
\text { fuel burning-derived } \\
\text { greenhouse gases } \\
\text { in the atmosphere }\end{array}$ \\
\hline
\end{tabular}

*Numbers from 1 to 47 correspond to the events reported in Table 1.

Own elaboration

These two identified visions on the relationship between growth and CC have been strongly influenced by the political-historical context where the reviewed events took place. For a better understanding of the two ways in which CC has been accordingly defined, a brief discussion of the features characterizing such political-historical contexts are discussed below.

\subsection{Dealing with climate change before the 1980s: growth as a driver}

The first calculation of global warming from human $\mathrm{CO}_{2}$ emissions was done at the end of the $19^{\text {th }}$ century (Arrehnius, 1896) ${ }^{9}$. However, research on the anthropogenic influence on climate only gained strength after World War II in a context of unprecedented, continuous exponential economic growth. By this time, a social debate was emerging on the global environmental effects from the expansion of human activities and their consequences on the ecological balance. This debate was furthered by increased awareness about the ecological limits to growth in a finite planet motivated by the multidimensional crisis of the 1970s linked to energy, economic, monetary, fiscal and sociopolitical issues as well as North-South and West-East disparities (Fernández-Durán, 2010; Fernández-Durán \& González-Reyes, 2018; Fontana, 2011). As highlighted in the Meadows report, concerns about absolute resource scarcity and ecological impacts as constraints to economic growth raised the need to alter growth trends and to establish a sustainable condition of ecological and economic stability (Meadows, Meadows, Randers, \& III, 1972). Although "no-growth" was considered an unviable policy (UNCHE, 1972) by the central global governance institutions ${ }^{10}$, rethinking the purposes of growth was viewed as necessary.

Thus research on anthropogenic CC was developed in a context where the public environmental debate revolved around the structural causes of ecological disruption and the purposes of growth. It nourished a broader scientific approach concerned with the disturbance of the planetary ecological balance by the industrial civilization metabolism. Such an approach built on Verdnasky (1926) which considered both the interrelated nature of atmospheric processes and that the volume of materials produced by human industry was approaching the scale of geological forces (Weart, 2008). Concerns about the ecological disruption by human activities were expressed at the 1955 monumental "Man's Role in Changing the Face of the Earth" Symposium organized by the influential historical and institutional geography 'school' of the University of Berkeley (Naredo \& Gutiérrez, 2005). Held in Princeton, it brought together scholars from all over the world working in a wide range of fields. Accordingly, climate researchers viewed the large scale of such a human-induced geophysical transformation as the mechanism through which concentrated organic carbon stored in sedimentary rocks over hundreds of millions of years was released into

9 Nevertheless, the discovery of both the ability of $\mathrm{CO}_{2}$ and water vapor to absorb heat and their direct link with $\mathrm{CC}$ dates back to the middle of the 19th century (Foote, 1856; Tyndall, 1861).

10 One exception was the 1974 Cocoyoc Symposium which openly challenged mainstream theories of growth and development (UNEP/ UNCTAD, 1974). 
the atmosphere and oceans (Revelle and Suess, 1957). They expected that the continuous exponential rise in fuel combustion derived from such a growth-oriented metabolism would have a significant impact on the radiation balance thus raising the average global temperature (Plass, 1956). Scientists agreed that the pursuit of economic growth was the main driver of global warming. The industrial metabolism fed by fossil fuel combustion was considered the major source of GHGs. Gradually, other CC determinants were also considered such as CFCs, methane or nitrates, among others. Since the beginning, climate science has followed an evolutionary process subject to many uncertainties leading to the gradual recognition that CC is a very complex phenomenon (Weart, 2008) ${ }^{11}$. CC was then viewed as another global environmental effect from the expansion of human technology and activities (Steffen, Crutzen, \& McNeill, 2007), as set out in the top climate conferences held before the 1980's.

\subsection{Shaping the global climate agenda from the 1980's onwards: growth as the solution}

The effects of the 1970s crisis allowed the election victories of Margaret Thatcher in the UK (1979) and Ronald Reagan in USA (1981). This gave way to an important world political and cultural change which weakened the labour movement and reduced the strength of the social mobilizations that had emerged from the 1968 protests (Fontana, 2018; Hobsbawm, 1994). It led to a series of privatizations, commodification and financialization processes (Fernández-Durán \& González-Reyes, 2018) which have come to be labelled as "neoliberalism" (Harvey, 2005). The privatization of public enterprises and services and the lower taxation of corporations, in addition to their tax evasion, alongside the cuts to public spending, marked the beginning of an era characterized by a gradual dismantling of the welfare state and rising inequality (Piketty, 2014; Saez \& Zucman, 2019). Since then, the "ethics" of the market exchange became dominant in both thought and practice throughout much of the world (Harvey, 2005), thus resulting in a further exacerbation of the planetary socioecological conflicts (Newell, 2011).

Accordingly, economic growth was enshrined as a global political objective by the advanced capitalist countries which believed it was a major ingredient for development (Redclift, 1987). Growth mystification was reinforced by the low prices of raw materials and oil and a stronger bargaining position of the wealthy countries at the global level (Naredo, 2006). As a result, absolute resource scarcity as a constraint to growth was no longer considered a concern in the sustainability governance sphere. Furthermore, the growth-fuelled intensive resource consumption led the rich nations to significantly increase their waste and emissions which contributed to convert pollution and CC into their main environmental concerns. The attention moved from resources to waste and from land to climate ${ }^{12}$, so the urgency of making structural analyses about the planetary ecological disruption disappeared (Fernández-Durán, 2010). However, as the risks of an ecological breakdown were increasing the statu quo defenders made efforts to "green" the concept of growth (Brand, 2012; Naredo, 2020). This led to the formation of the World Commission on Environment and Development (WCED) in 1983 which published the Brundtland report in 1987. Under the title "Our Common Future", this report presented the term of sustainable development (SD) assuming growth was a key component for development and protection of nature, thus supporting growth over the long-term (WCED, 1987). Therefore, growth was no longer viewed as a driver of ecological decline but as the solution to social and environmental problems (Gómez-Baggethun \& Naredo, 2015).

Following conventional economics reasoning, the Brundtland report considered poverty and the unintended growth-derived externalities as the main environmental challenges (WCED, 1987). So CC was viewed as a market failure to be corrected through the monetary valuation of fossil fuel burning-generated emissions and market-based environmental policy tools. Voices claiming the growth-based expansion of human activities as the main CC driver (emphasizing the interrelated nature of atmospheric processes) were silenced at the international governance level. Energy transition through efficiency improvement measures and investment in low carbon/renewable energy by corporations became the pillars of mitigation. The report presented solutions to CC in the form of energy choices for the environment and (growth-based) development. Though the WCED recognized the reduction of energy consumption

11 This explains why some of the causes initially thought to explain CC (like the ozone layer depletion) are not considered today determinants of it.

12 This shift was evidenced at the 1987 "The Earth as Transformed by Human Action" Symposium, as denounced at the 2005 "Man's Role in Changing the Face of the Earth" Symposium held in Lanzarote to commemorate the 50th anniversary of that held in Princeton (Naredo \& Gutiérrez, 2005). 
as crucial to achieving a sustainable future, it considered improvements in energy efficiency and transforming the energy mix towards a major share of renewables was more urgent (WCED, 1987). This not only showed optimism towards technological solutions but also presented investment in technology as a new path for growth. The valuation of energy's external damage costs and carbon markets have since become essential mitigation mechanisms (Bryant, 2018) as stated in the main international climate-focused events taking place after 1987.

\section{Discussion of results}

A historical analysis of the main international climate-focused events shows a growth-oriented discursive shift in the 1980's which moved the attention from mankind's impacts on climate to GHG emissions to the atmosphere. As we critically discuss in the following sections, as a result of this shift a carbon agenda highly reliant on technological solutions dominates today the global climate policy leading to believe GHG emissions can be decoupled from GDP.

\subsection{The carbon agenda}

In an era of corporate globalisation enshrining economic growth and shaping accordingly a growthoriented GCA, CC needed to be redefined. A new narrative was required to shift attention from the planetary ecological impacts of the growth-driven expansion of human activities to the fossil fuel burning-derived gases "unintendedly" put into the atmosphere. Redefining CC as a negative externality from certain forms of growth was useful to the multinational corporations as it stimulated an emerging green capitalism which viewed nature as a new frontier of capital accumulation (Smith, 2007). The Brundtland report-based SD concept served as a wake-up call to initiate a climate agenda serving an elite minority eagerly searching for new profit-making opportunities. Focusing on the need to "decarbonize" the economy has contributed to developing a climate commodification and financialization process (Bailey, 2017; Lohmann, 2006; Paterson, 2001) where carbon emissions can be added, subtracted, moved or compensated through projects supported by green finance (Castree \& Christophers, 2015). A carbon agenda in the form of carbon budgets, carbon goals, carbon prices and carbon markets dominates today the international climate policy driven by an excessive reliance on technological solutions. The faith in technology such a carboncentric perspective builds on leads to believe unlimited growth is possible (Bailey, Gouldson, \& Newell, 2011; Cavagnaro \& Curiel, 2012) through investments in technologies around renewable energy, energy efficiency, low carbon/non-carbon transport and emission compensation mechanisms (Paterson, 2001). On the basis of an ecological modernization discourse, it leads to believe green growth is possible and the solution to CC.

However, this converts carbon metrics into a key tool to assess climate policies which are consequently considered as "good" if providing a reduction or net reduction of $\mathrm{CO}_{2}$ emissions, thus leading to short process analyses overlooking the rest of realities and their links (Moreno et al., 2016). It restricts the policy debate to discussions about end-of-pipe technological solutions (O'Brien, 2018) and demand reduction options involving changes in logistics and lifestyle (Sharmina et al., 2020). The conventional economics approach treats GHG emissions only as a technical question of correcting market failures ignoring the social and political aspects involving mitigation and adaptation (Bailey, 2017). As Moreno et al. (2016) state, proposing solutions based on low carbon/renewable technologies and market-based instruments do not question the current socioeconomic order but reassert it. Even more, the existing optimism towards technological solutions has led to view adaptation as a priority policy (IPCC, 2001), thus further moving the attention away from the debate on the need to change the rules driving the world economy (Mussetta, 2020). However, this debate is essential especially in a context where supply risks for some of the raw materials required to develop green technologies are high (Valero, Valero, Calvo, \& Ortegoa, 2018).

\subsection{The illusion of growth-based sustainable development or green growth}

The SD concept which the current GCA builds on considers growth as a key ingredient for development, this converting SD into an oxymoron. The concept's wide acceptance by conservationists and conventional economists can be explained by the ambiguity of a term trying to conciliate two notions referring to different abstraction and reasoning systems levels: growth-based development 
and sustainability. As Naredo (2015) states, such development involves the growth of the aggregated production which represents today only a monetary magnitude. As production is not linked to the physical world, it is assumed it can grow unlimitedly. In contrast, sustainability concerns heterogeneous physical processes considering the second thermodynamics law. The social progress virtues which have been usually attributed to growth helps to explain why the SD advocated for by the central sustainability governance institutions is viewed not only as possible but also as desirable (Valladares, Magro, \& MartínForés, 2019).

However, the SD-induced idea that continued economic expansion is compatible with planet's ecology, which was formalized at the Rio+20 Summit (Hickel \& Kallis, 2020) through the new oxymoron of green growth (Brand, 2012) ${ }^{13}$, lacks empirical support. The belief technology and substitution can improve resource efficiency with the help of market-based environmental policy tools have been refuted by empirical data. Evidence shows GDP growth cannot be decoupled from growth in material and energy use (Haberl et al., 2020; Vadén et al., 2020; Ward et al., 2016; Wiedenhofer et al., 2020) as it requires the appropriation of physical resources (Cavagnaro \& Curiel, 2012). Besides, physical limits governing efficiency gains make permanent decoupling (absolute or relative) impossible for essential, non-substitutable resources (Ward et al., 2016). Although global historical trends show some relative decoupling, no evidence exists of absolute decoupling, the beginning of the $21^{\text {st }}$ century showing worse efficiency and re-coupling occurring (Hickel \& Kallis, 2020). The Kuznets Kurve-inspired hypothesis of dematerialization with GDP growth has only happened in developed countries via outsourcing industrial activity to developing ones with cheaper labour force and softer environmental regulation standards (Gómez-Baggethun \& Naredo, 2015; Özokcu \& Özdemir, 2017).

Consequently, empirical data also shows a positive correlation between global GDP and emissions (Tapia, Ionides, \& Carpintero, 2012). Given CC derives from the growth-oriented metabolism of the current socioeconomic system (Schandl et al., 2018), emissions cannot be decoupled from resource use and hence from growth at a planetary scale. This also applies to the Global North despite some recent examples of absolute GDP decoupling from emissions. Energy transition also has resource requirements which will lead to rising energy demand in a context of technical limitations and rebound effects (Wiedmann, Lenzen, Keyßer, \& Steinberger, 2020). Hickel and Kallis (2020) argue that, while absolute decoupling is happening in some regions, it is unlikely to happen fast enough to reach the $1.5^{\circ} \mathrm{C} / 2^{\circ} \mathrm{C}$ Paris goals if growth continues as it stimulates energy demand. Emission reduction efforts will have to be not only maintained but strengthened to support a global peak in emissions followed by global emissions falls (Le Quéré et al., 2019).

\section{Conclusions}

This paper has examined the GCA growth roots to shed some light on whether the rules driving the world economy are shaping it. These rules build on the growth ideology fuelling the current extractivist socioeconomic metabolism lying behind the actual planetary socioecological crisis. The fact that global emissions have kept growing since such an agenda took off thirty years ago proves the international climate policy is growth-oriented, thus responding to the interest of the powerful to maintain the status quo. Such an orientation appears as the main driver of climate policy failure. A SD notion assuming growth is essential for development leads to frame the policy debate within the discussion about the need for both "decarbonizing" the economy through energy transition and CC adaptation. Then it results in a policy architecture highly reliant on technological solutions and market-based instruments, which views emissions as easy to handle "LEGO pieces" which can be added, subtracted, moved or compensated. It results in a policy architecture subject to the Global North's plans and consequently to the goodwill of both the signatory governments and the "major pollution players". As their emissions remain outside the bounds of the national jurisdiction (Ivanovich, Ocko, Piris-Cabezas, \& Petsonk, 2019), aviation and shipping have not been directly included in the Paris Agreement. This further exacerbates the ineffectiveness of the climate

13 At the Rio+20 Summit, the UN Member States decided to launch a process to develop a set of Sustainable Development Goals (SDG) to build upon the MDGs which led to adopt the 2030 Agenda for Sustainable Development at the 2015 UN Sustainable Development Summit (https://sdgs.un.org/es/goals, accessed 15 April 2021). Considering "Decent Work and Economic Growth" and "Climate Action" as 2 of the 17 SDGs being at the core of the 2030 Agenda (8 SDG and 13 SDG, respectively) further demostrates the general assumed idea that (growth-based) SD is needed to fight against CC. 
policy especially in a context where aviation emissions have been recently found to warm the climate at approximately three times the rate of that associated with aviation $\mathrm{CO}_{2}$ emissions alone (Lee et al., 2021).

Combined, this has led us to believe green growth is possible and the solution to CC. However, under continued GDP growth evidence shows no absolute decoupling from resource use on a global scale and the impossibility to achieve absolute decoupling from carbon emissions at the rate required by the Paris Agreement (Hickel \& Kallis, 2020). The green growth objective pursued by the central climate governance institutions is undoubtedly misguided. Despite this, the European Green Deal (EGD), which includes the European Climate Pact, considers a new growth strategy is needed for the EU to overcome all environmental challenges. Even more so, the European Commission's proposal for the first European Climate Law aims to write into law the EGD goal. The 2030 Agenda-related 17 SDG express the belief that growth is not only needed for development (8 SDG), but also compatible with climate action (13 SDG). The contradictions between growth and sustainable resource use (Eisenmenger et al., 2020) do not seem to be reasons enough for the UN Member States to understand why action to meet the goals is not advancing at the speed or scale required. Power dynamics and interactions between injustices underlying the SDGs are not questioned (Wiedmann et al., 2020). Even worse, the International Energy Agency satisfactorily forecasts GDP will return to pre-crisis levels in 2021 assuming the pandemic is brought under control (IEA, 2020).

By the end of 2019 more than 11,000 scientists from around the world declared planet Earth is facing a climate emergency and called for urgent action (Ripple et al., 2020). In recent years, new youth-led global movements such as Fridays for Future, Extinction Rebellion and By2020WeRiseUp have emerged claiming for an immediate and convincing climate action to avoid the $1.5^{\circ} \mathrm{C}$ temperature increase. Other social movements, such as the Degrowth Movement, the Green New Deal for Europe or the International Progressive are also gaining strength in the actual context of socioecological crisis. Many researchers from all over the world working in a wide range of fields have long been denouncing the world economy functioning. The role of geographers in emphasizing the need to understand CC from a holistic perspective has especially been prominent as already shown by the Princeton symposium almost three quarters of century ago. Indeed, geographers associations, such as the International Geographical Union or the Spanish Geographical Association, keep reminding us of the role of geography as a major science in global debates on climate change. Together with all these scholars, social movements claim for scaling down aggregate energy use to move to a different socioeconomic system respecting the planetary boundaries. They have put again on the table the public debate on the limits to growth. The European Environment Agency recently warned Europe will not live well with the planet's limits by continuing to promote growth (EEA, 2019).

In the Anthropocene era of human activities shaping the face of Earth (Elhacham, Ben-Uri, Grozovski, Bar-On, \& Milo, 2020), where CC acts as a synecdoche for their derived ecological impacts (Hulme, 2017), the GCA needs a 180-degree turn. Urgent, transformative action is required (Dryzek, 2016; Mastini, Kallis, \& Hickel, 2021; Wamsler et al., 2020). CC must be repoliticized (Liverman, 2015). Considering the role of politics and power in perpetuating business as usual is essential to ensure coherent transformative responses which question existing thought paradigms and patterns (O'Brien, 2017). The COVID-19 pandemic should serve as a wake-up call to tackle the climate crisis even more urgently and move toward a better future (Perkins, Munguia, Ellenbecker, Moure-Eraso, \& Velazquez, 2020). Acting on the direct drivers of nature decline is not sufficient to prevent further planetary ecological deterioration, as it also requires addressing the root economic, sociocultural, demographic, political, institutional and technological causes behind them (Díaz et al., 2019). Moving beyond GDP growth then becomes an urgent need (Kuhnhenn, Costa, Mahnke, Schneider, \& Lange, 2020).

The mechanisms ruling the world economy have to be challenged. This challenge is however large (Capellán-Pérez, Mediavilla, de Castro, Carpintero, \& Miguel, 2015; Millward-Hopkins, Steinberger, Rao, $\&$ Oswalda, 2020). The structural imperative for growth in the current socioeconomic order will make societal change difficult (Wiedmann et al., 2020) as growth is equated with human progress, power and welfare (Kallis et al., 2018; Naredo, 2015). As an ideology, growth dangerously filters the messages sent by climate scientists on urgent action leading to keep things unchanged (Dryzek et al., 2013). In the meantime, planet Earth keeps warming. 2019 was the second warmest year in the 140-year record with the temperature for 2020 October being the fourth-highest for October behind that of 2015, 2018 and 2019 Octobers (NOAA, 2020, 2019). If CC continues, future projections point to a potentially 
catastrophic global biodiversity loss (Trisos, Merow, \& Pigot, 2020). So, no matter how big the challenge of going beyond growth is, the CC challenge is much bigger. The global climate policy will have to go beyond growth sooner or later. A finite planet with limited resources does not allow for other policy options. Social pressure on the institutions is needed to force them to develop a new climate agenda. Let's not make more mistakes to avoid losing the Earth (Rich, 2020). Let's act now before it is too late.

\section{Acknowledgements}

We acknowledge José Manuel Naredo for inspiring and enlightening us, Óscar Carpintero for his selfless help and key suggestions and Katherine Needham for her useful comments on an earlier version of the paper.

\section{References}

Arrehnius, S. (1896). On the Influence of Carbonic Acid in the Air upon the Temperature of the Ground. In J. P. Howe (Ed.), Making Climate Change History: Documents from Global Warming's Past (pp. 39-44 (2017)). London: University of Washington Press.

Arrighi, G. (2009). Long Twentieth Century: Money, Power and the Origins of Our Time. New York: Verso Books.

Ash, C., Culotta, E., Fahrenkamp-Uppenbrink, J., Malakoff, D., Smith, J., Sugden, A., \& Vignieri, S. (2013). Once and Future Climate Change. Science, 341(6145), 472-473. https://doi.org/10.1126/ science.341.6145.472

Bailey, I. (2017). Climate change policy. The International Encyclopedia of Geography, 1-12. https://doi. org/10.1002/9781118786352.wbieg0537

Bailey, I., Gouldson, A., \& Newell, P. (2011). Ecological Modernisation and the Governance of Carbon: A Critical Analysis. Antipode, 43(3), 682-703. https://doi.org/10.1111/j.1467-8330.2011.00880.x

Boulding, K. (1966). The economics of the coming spaceship earth. In H. Jarrett (Ed.), Environmental Quality in A Growing Economy: Essays from the Sixth RFF Forum (pp. 1-20). Baltimore: Johns Hopkins Press.

Brand, U. (2012). Green Economy - the next oxymoron? No lessons learned from failures of implementing sustainable development. GAIA - Ecological Perspectives for Science and Society, 21(1), 28-32. https:// doi.org/10.14512/gaia.21.1.9

Bryant, G. (2018). Nature as Accumulation Strategy? Finance, Nature, and Value in Carbon Markets. Annals of the American Association of Geographers, 108(3), 605-619. https://doi.org/10.1080/246944 52.2017.1375887

Capellán-Pérez, I., Mediavilla, M., de Castro, C., Carpintero, Ó., \& Miguel, L. J. (2015). More growth? An unfeasible option to overcome critical energy constraints and climate change. Sustainability Science, 10(3), 397-411. https://doi.org/10.1007/s11625-015-0299-3

Castree, N., \& Christophers, B. (2015). Banking Spatially on the Future: Capital Switching, Infrastructure, and the Ecological Fix. Annals of the Association of American Geographers, 105(2), 378-386. https:// doi.org/10.1080/00045608.2014.985622

Cavagnaro, E., \& Curiel, G. (2012). The three levels of sustainability. Sheffield: Greenleaf Publishing.

Ciplet, D., \& Roberts, J. T. (2017). Climate change and the transition to neoliberal environmental governance. Global Environmental Change, 46, 148-156. https://doi.org/10.1016/j.gloenvcha.2017.09.003

Díaz, S., Settele, J., Brondízio, E. S., Ngo, H. T., Agard, J., Arneth, A., ... Zayas, C. N. (2019). Pervasive human-driven decline of life on Earth points to the need for transformative change. Science, 366(1327), 1-12. https://doi.org/10.1126/science.aax3100

Dorninger, C., Hornborg, A., Abson, D. J., von Wehrden, H., Schaffartzik, A., Giljum, S., .. Wieland, H. (2021). Global patterns of ecologically unequal exchange: Implications for sustainability in the 21st century. Ecological Economics, 179, 106824. https://doi.org/10.1016/j.ecolecon.2020.106824

Dryzek, J. S. (2016). Institutions for the Anthropocene: Governance in a Changing Earth System. British Journal of Political Science, 46(4), 937-956. https://doi.org/10.1017/S0007123414000453 
Dryzek, J. S., Norgaard, R. B., \& Scholsberg, D. (2013). Climate-challenged society (169th ed.). Oxford, UK: Oxford University Press. https://doi.org/10.1093/oso/9780199660100.001.0001

Edgerton, D. (2018). The Rise and Fall of the British Nation: A Twentieth-Century History. 01 edition. London, UK: Allen Lane.

EEA (European Environment Agency). (2019). The European environment - state and outlook 2020 (SOER 2020). Copenhagen, Denmark.

Eisenmenger, N., Pichler, M., Krenmayr, N., Noll, D., Plank, B., Schalmann, E., .. Gingrich, S. (2020). The Sustainable Development Goals prioritize economic growth over sustainable resource use: a critical reflection on the SDGs from a socio-ecological perspective. Sustainability Science, 15, 11011110. https://doi.org/10.1007/s11625-020-00813-x

Elhacham, E., Ben-Uri, L., Grozovski, J., Bar-On, Y. M., \& Milo, R. (2020). Global human-made mass exceeds all living biomass. Nature. https://doi.org/10.1038/s41586-020-3010-5

Fernández-Durán, R. (2010). Fin del Cambio Climático como vía para "Salvar todos juntos el Planeta". Boletín $C F+S, 46$.

Fernández-Durán, R., \& González-Reyes, L. (2018). En la espiral de la energía. Volumen I. Historia de la humanidad desde el papel de la energía (pero no solo) (2nd ed.). Madrid and País Valencià: Libros en Acción and Baladre.

Fontana, J. (2011). Por el bien del imperio. Una historia del mundo desde 1945. Barcelona: Ediciones de Pasado y Presente, SL.

Fontana, J. (2018). L'ofici d'historiador. Barcelona: Càtedra Ferrater Mora de Pensament Contemporani, Universitat de Girona, and ATMARCADIA, SL.

Foote, E. (1856). Circumstances affecting the heat of the Sun's rays. Americal Journal of Science and Arts, 22, 382-383.

Foster, J. B., \& Clark, B. (2012). The Planetary Emergency. Monthly Review, 64(7). https://doi.org/10.14452/ MR-064-07-2012-11_1

Friedlingstein, P., O’Sullivan, M., Jones, M. W., Andrew, R. M., Hauck, J., Olsen, A., ... Zaehle, S. (2020). Global Carbon Budget 2020. Earth System Science Data, 12(4), 3269-3340. https://doi.org/10.5194/ essd-12-3269-2020

Gil, A., \& Olcina, J. (2021). Tratado de Climatología (2nd ed.). Alicante: Publicaciones de la Universidad de Alicante.

Gómez-Baggethun, E., \& Naredo, J. M. (2015). In search of lost time: the rise and fall of limits to growth in international sustainability policy. Sustainability Science, 10(3), 385-395. https://doi.org/10.1007/ s11625-015-0308-6

Haberl, H., Wiedenhofer, D., Pauliuk, S., Krausmann, F., Müller, D. B., \& Fischer-Kowalski, M. (2019). Contributions of sociometabolic research to sustainability science. Nature Sustainability, 2(3), 173184. https://doi.org/10.1038/s41893-019-0225-2

Haberl, H., Wiedenhofer, D., Virág, D., Kalt, G., Plank, B., Brockway, P., ... Creutzig, F. (2020). A systematic review of the evidence on decoupling of GDP, resource use and GHG emissions, part II: synthesizing the insights. Environmental Research Letters, 15(6), 065003. https://doi.org/10.1088/1748-9326/ $\underline{\mathrm{ab} 842 \mathrm{a}}$

Hammond, A. L. (1972). Inadvertent Climate Modification. Report of the Study of Man's Impact on Climate (SMIC). M. I. T. Press, Cambridge, Mass., 1971. xxiv, 308 pp., illus. Paper, \$2.95. Science, 176(4030), 38-38. https://doi.org/10.1126/science.176.4030.38-a

Harvey, D. (2005). A Brief History of Neoliberalism. Oxford: Oxford University Press. https://doi. org/10.1093/oso/9780199283262.003.0010

Helm, D. (2008). Climate-change policy: why has so little been achieved?. Oxford Review of Economic Policy, 24(2), 211-238. https://doi.org/10.1093/oxrep/grn014

Hickel, J., \& Kallis, G. (2020). Is Green Growth Possible?. New Political Economy, 25(4). https://doi.org/ $\underline{10.1080 / 13563467.2019 .1598964}$

Hobsbawm, E. (1994). The Age Of Extremes. A history of the world, 1914-1991. US: Vintage Books. 
Hulme, M. (2017). Climate change, concept of. The International Encyclopedia of Geography. https://doi. org/10.1002/9781118786352.wbieg0343

Hulme, M. (2020). Intergovernmental Panel on Climate Change (IPCC). The International Encyclopedia of Geography. https://doi.org/10.1002/9781118786352.wbieg0254.pub2

IEA. (2020). World Energy Outlook 2020. Paris, Organization for Economic Cooperation and Development/ International Energy Agency.

IPCC (Intergovernmental Panel on Climate Change). (2001). Climate Change 2001: Synthesis Report. A Contribution of Working Groups I, II, and III to the Third Assessment Report of the Integovernmental Panel on Climate Change [Watson, R.T. and the Core Writing Team (eds.)]. Cambridge University Press. Cambridge, United Kingdom, and New York, NY, USA.

IPCC (Intergovernmental Panel on Climate Change). (2014). Climate Change 2014: Synthesis Report. Contribution of Working Groups I, II and III to the Fifth Assessment Report of the Intergovernmental Panel on Climate Change [Core Writing Team, R.K. Pachauri and L.A. Meyer (eds.)]. Geneva, Switzerland.

IPCC (Intergovernmental Panel on Climate Change). (2018). Global Warming of 1.5 ${ }^{\circ}$. An IPCC Special Report on the impacts of global warming of $1.5^{\circ} \mathrm{C}$ above pre-industrial levels and related global greenhouse gas emission pathways, in the context of strengthening the global response to the threat of climate change, sustainable development, and efforts to eradicate poverty [Masson-Delmotte, V., P. Zhai, H.-O. Pörtner, D. Roberts, J. Skea, P.R. Shukla, A. Pirani, W. Moufouma-Okia, C. Péan, R. Pidcock, S. Connors, J.B.R. Matthews, Y. Chen, X. Zhou, M.I. Gomis, E. Lonnoy, T. Maycock, M. Tignor, and T. Waterfield (eds.)]. In Press.

Ivanovich, C. C., Ocko, I. B., Piris-Cabezas, P., \& Petsonk, A. (2019). Climate benefits of proposed carbon dioxide mitigation strategies for international shipping and aviation. Atmospheric Chemistry and Physics, 14949-1496. https://doi.org/10.5194/acp-19-14949-2019

Kallis, G., Kostakis, V., Lange, S., Muraca, B., Paulson, S., \& Schmelzer, M. (2018). Research on degrowth. Annual Review of Environment and Resources, 43, 291-316. https://doi.org/10.1146/annurevenviron-102017-025941

Keeling, C. D. (1960). The concentration and isotopic abundances of carbon dioxide in the atmosphere. Tellus, XII(2), 200-203. https://doi.org/10.3402/tellusa.v12i2.9366

Kellogg, W. W. (1987). Mankind's impact on climate: the evolution of an awareness. Climatic Change, 10, 113-136. https://doi.org/10.1007/BF00140251

Klein, N. (2014). This changes everything. London, United Kingdom: Penguin Books Ltd.

Klein, N. (2020). On Fire: The Burning Case for a Green New Deal. London, United Kingdom: Penguin Books Ltd.

Krausmann, F, Lauk, C., Haas, W., \& Wiedenhofer, D. (2018). From resource extraction to outflows of wastes and emissions: The socioeconomic metabolism of the global economy, 1900-2015. Global Environmental Change, 52, 131-140. https://doi.org/10.1016/j.gloenvcha.2018.07.003

Kuhnhenn, K., Costa, L., Mahnke, E., Schneider, L., \& Lange, S. (2020). A Societal Transformation Scenario for Staying Below $1.5^{\circ} \mathrm{C}$. Berlin: Volume 23 of the Publication Series Economic \& Social Issues. Heinrich Böll Foundation and Konzeptwerk Neue Ökonomie 2020.

Kuyper, J., Schroeder, H., \& Linnér, B.-O. (2018). The Evolution of the UNFCCC. Annual Review of Environment and Resources, 43(1), 343-368. https://doi.org/10.1146/annurev-environ-102017-030119

Le Quéré, C, Korsbakken, J., Wilson, C., Andrew, R., Andres, R., Canadell, J., ... van Vuuren, D. (2019). Drivers of declining CO2 emissions in 18 developed economies. Nature Climate Change, 9, $213-217$. https://doi.org/10.1038/s41558-019-0419-7

Le Quéré, Corinne, Jackson, R. B., Jones, M. W., Smith, A. J. P., Abernethy, S., Andrew, R. M., ... Peters, G. P. (2020). Temporary reduction in daily global CO2 emissions during the COVID-19 forced confinement. Nature Climate Change, 10, 647-653. https://doi.org/10.1038/s41558-020-0797-x

Le Treut, H., Somerville, R., Cubasch, U., Ding, Y., Mauritzen, C., Mokssit, A., ... Prather, M. (2007). Historical Overview of Climate Change. In S. Solomon, D. Qin, M. Manning, Z. Chen, M. Marquis, K. B. Averyt, ... H. L. Miller (Eds.), Climate Change 2007: The Physical Science Basis. Contribution of Working Group I to the Fourth Assessment Report of the Intergovernmental Panel on Climate Change. Cambridge, United Kingdom and New York, NY, USA.: Cambridge University Press. 
Lee, D., Fahey, D., Skowron, A., Allen, M., Burkhardt, U., Chen, Q., ... Wilcox, L. (2021). The contribution of global aviation to anthropogenic climate forcing for 2000 to 2018. Atmospheric Environment, 244(117834). https://doi.org/10.1016/j.atmosenv.2020.117834

Liu, Z., Ciais, P., Deng, Z., \& Al., E. (2020). Near-real-time monitoring of global CO2 emissions reveals the effects of the COVID-19 pandemic. Nature Communications, 11(5172). https://doi.org/10.1038/ s41467-020-18922-7

Liverman, D. (2015). Reading Climate Change and Climate Governance as Political Ecologies. In T. Perreault, G. Bridge, \& J. McCarthy (Eds.), The Routledge Handbook of Political Ecology (pp. 303-319). Routledge.

Lohmann, L. (2006). Carbon Trading. A critical conversation on climate change, privatisation and power. Development Dialogue, 48.

MacDonald, G. J. F. (1966). Weather and climate modification-problems and prospects. Bulletin of the American Meteorological Society, 47(1), 4-20. https://doi.org/10.1175/1520-0477-47.1.4

Malm, A. (2016). Fossil Capital: The Rise of Steam Power and the Roots of Global Warming. London: Verso.

Martín, J., \& Gallego, J. L. (2010). Apaga la luz. El libro sobre el cambio climático. Barcelona: Davinci Continental.

Mastini, R., Kallis, G., \& Hickel, J. (2021). A Green New Deal without growth?. Ecological Economics, 179, 106832. https://doi.org/10.1016/j.ecolecon.2020.106832

McCarthy, J. (2015). A socioecological fix to capitalist crisis and climate change? The possibilities and limits of renewable energy. Environment and Planning A: Economy and Space, 47(12), 2485-2502. https://doi.org/10.1177/0308518X15602491

McNutt, M. (2013). Climate Change Impacts. Science, 341(6145), 435-435. https://doi.org/10.1126/ science. 1243256

Meadows, D. H., Meadows, D. L., Randers, J., \& III, W. W. B. (1972). The limits to growth. New York: Universe Books.

Millward-Hopkins, J., Steinberger, J. K., Rao, N. D., \& Oswalda, Y. (2020). Providing decent living with minimum energy: A global scenario. Global Environmental Change, 65. https://doi.org/10.1016/j. gloenvcha.2020.102168

Milne, S. (2014). The Enemy Within. The Secret War Against the Miners (4th ed.). London, UK: Verso.

Moreno, C., Speich, D., \& Fuhr, L. (2016). Carbon Metrics. Global abstractions and ecological epistemicide. Volume 42 of the Publication Series Ecology. Heinrich Böll Foundation.

Mussetta, P. (2020). La adaptación como respuesta al cambio climático. Notas acerca de las contracaras de un paradigma dominante. Scripta Nova, XXIV(634). https://doi.org/10.1344/sn2020.24.27841

Naredo, J. M. (2006). Raíces económicas del deterioro ecológico y social. Más allá de los dogmas. Madrid: Siglo XXI de España Editores, S.A.

Naredo, J. M. (2015). La economía en evolución (4th ed.). Madrid: Siglo XXI de España Editores, S.A.

Naredo, J. M. (2020). Sobre las preocupaciones y metas del movimiento ecologista. Comentarios y aportaciones a los diccionarios del desarrollo (1992) y del posdesarrollo (2019). Biblio3W, XXV(1296), $1-34$.

Naredo, J. M., \& Gutiérrez, L. (Eds.). (2005). La incidencia de la especie humana sobre la faz de la Tierra (1955-2005). Granada: Universidad de Granada and Fundación César Manrique.

Newell, P. (2011). The elephant in the room: Capitalism and global environmental change. Global Environmental Change, 21(1), 4-6. https://doi.org/10.1016/j.gloenvcha.2010.11.011

Newell, P. (2012). Globalization and the Environment: Capitalism, Ecology and Power. United Kingdom: Polity Press.

Nieto, J., Carpintero, Ó., \& Miguel, L. J. (2018). Less than 2C? An economic-environmental evaluation of the Paris Agreement. Ecological Economics, 146, 69-84. https://doi.org/10.1016/j.ecolecon.2017.10.007

Nieto, Jaime, Carpintero, Ó., \& Miguel, L. J. (2018). Less than 2C? An economic-environmental evaluation of the Paris Agreement. Ecological Economics, 146, 69-84. https://doi.org/10.1016/j. ecolecon.2017.10.007 
NOAA (National Oceanic and Atmospheric Administration). (2019). Global Climate Report - Annual 2019. Asheville, North Carolina.

NOAA (National Oceanic and Atmospheric Administration). (2020). Global Climate Report - October 2020. Asheville, North Carolina.

O'Brien, K. (2017). Climate change adaptation and social transformation. The International Encyclopedia of Geography. https://doi.org/10.1002/9781118786352.wbieg0987

O'Brien, K. (2018). Is the $1.5^{\circ} \mathrm{C}$ target possible? Exploring the three spheres of transformation. Current Opinion in Environmental Sustainability, 31, 153-160. https://doi.org/10.1016/j.cosust.2018.04.010

Özokcu, S., \& Özdemir, Ö. (2017). Economic growth, energy, and environmental Kuznets curve. Renewable and Sustainable Energy Reviews, 72, 639-647. https://doi.org/10.1016/j.rser.2017.01.059

Paterson, M. (2001). Climate policy as accumulation strategy: the failure of COP6 and emerging trends in climate politics. Global Environmental Politics, 1(2), 10-17. https://doi. org/10.1162/152638001750336550

Pauliuk, S., \& Hertwich, E. (2015). Socioeconomic metabolism as paradigm for studying the biophysical basis of human societies. Ecological Economics, 119, 83-93. https://doi.org/10.1016/j. ecolecon.2015.08.012

Pelling, M. (2011). Adaptation to Climate Change: From Resilience to Transformation. London: Routledge. https://doi.org/10.4324/9780203889046

Perkins, K. M., Munguia, N. E., Ellenbecker, M., Moure-Eraso, R., \& Velazquez, L. E. (2020). COVID-19 Pandemic Lessons to Facilitate Future Engagement in the Global Climate Crisis. Journal of Cleaner Production, In Press. https://doi.org/10.1016/j.jclepro.2020.125178

Piketty, T. (2014). Capital in the Twenty-First Century. Cambridge, MA: Harvard University Press. https:// doi.org/10.4159/9780674369542

Plass, G. N. (1956). The carbon dioxide theory of climate change. Tellus, VIII(2), 140-154. https://doi. org/10.3402/tellusa.v8i2.8969

Redclift, M. (1987). Sustainable development. Exploring the contradictions. London: Taylor \& Francis e-Library.

Revelle, R., \& Suess, H. E. (1957). Carbon dioxide exchange between atmosphere and ocean and the question of an increase of atmospheric CO2 during the past decades. Tellus, 9(1), 18-27. https://doi. org/10.3402/tellusa.v9i1.9075

Rich, N. (2020). Perdiendo la Tierra. La década en que podríamos haber detenido el cambio climático. Madrid: Capitán Swing.

Ripple, W. J., Wolf, C., Newsome, T. M., Barnard, P., Moomaw, W. R., \& Altere. (2020). World Scientists' Warning of a Climate Emergency. BioScience, 70(1).

Ripple, W. J., Wolf, C., Newsome, T. M., Galetti, M., Alamgir, M., Crist, E., ... Laurance, W. F. (2017). World Scientists' Warning to Humanity: A Second Notice. BioScience, 67(12), 1026-1028. https://doi. org/10.1093/biosci/bix125

Romero, J., \& Olcina, J. (Eds.). (2021). Cambio climático en el Mediterráneo. Procesos, riesgos y políticas. Valencia: Tirant lo Blanc.

Saez, E., \& Zucman, G. (2019). The triumph of Injustice. New York: W.W. Norton \& Company Ltd.

SCEP (Study of Critical Environmental Problems). (1970). Man's Impact on the Global Climate: Report of the Study of Critical Environmental Problems. Cambridge, Massachusetts.

Schandl, H., Fischer-Kowalski, M., West, J., Giljum, S., Dittrich, M., Eisenmenger, N., ... Fishman, T. (2018). Global Material Flows and Resource Productivity: Forty Years of Evidence. Journal of Industrial Ecology, 22(4), 827-838. https://doi.org/10.1111/jiec.12626

Sharmina, M., Edelenbosch, O. Y., Wilson, C., Freeman, R., Gernaat, D. E. H. J., Gilbert, P., .. Quéré, C. Le. (2020). Decarbonising the critical sectors of aviation, shipping, road freight and industry to limit warming to $1.5-2^{\circ} \mathrm{C}$. Climate Policy, Ahead-of-p, 1-20. https://doi.org/10.1080/14693062.2020.183 $\underline{1430}$ 
SMIC (Study of Man's Impact on Climate). (1971). Inadvertent Climate Modification. Report of the Study of Man's Impact on Climate (SMIC). Cambridge, Massachusetts.

Smith, N. (2007). Nature as an accumulation strategy. In C. Leys and L. Panitch (Eds), The Socialist Register 2007: Coming to Terms with Nature (pp. 16-36). London: Merlin.

Steffen, W., Crutzen, P.J., \& McNeill, J. R. (2007). The Anthropocene: Are Humans Now Overwhelming the Great Forces of Nature? Ambio, 36(8), 614-621. https://doi.org/10.1579/0044-7447(2007)36[614:TA AHNO]2.0.CO;2

Stevenson, H. (2021). Reforming global climate governance in an age of bullshit. Globalizations, 18(1), 86-102. https://doi.org/10.1080/14747731.2020.1774315

Stevenson, H., \& Dryzek, J. S. (2013). Democratizing Global Climate Governance. Cambridge: Cambridge University Press. https://doi.org/10.1017/CBO9781139208628

Tapia, J. A., Ionides, E. L., \& Carpintero, Ó. (2012). Climate change and the world economy: shortrun determinants of atmospheric CO2. Environmental Science \& Policy, 21, 50-62. https://doi. org/10.1016/j.envsci.2012.03.008

Thatcher, M. (2002). Statecraft. Strategies for a changing world. New York: HarperCollins.

Trisos, C. H., Merow, C., \& Pigot, A. L. (2020). The projected timing of abrupt ecological disruption from climate change. Nature, 580, 496-501. https://doi.org/10.1038/s41586-020-2189-9

Tyndall, J. (1861). The Bakerian Lecture: on the absorption and radiation of heat by gases and vapours, and on the physical connexion of radiation, absorption, and conduction. Philosophical Transactions. The Royal Society, 151, 28-29. https://doi.org/10.1098/rstl.1861.0001

UNCHE (United Nations Conference on the Human Environment). (1972). Report of the United Nations Conference on the Human Environment (p. 81). New York.

UNEP/UNCTAD (United Nations Development Programme/United Nations Comission on Trade and Development). (1974). Patterns of resource use, environment and development strategies. Cocoyoc, Mexico, October 8-12, 1974.

UNFCCC. (1997). Kyoto Protocol to the United Nations Framework Convention on Climate Change. December 1st-10th, 1997. United Nations. Retrieved from https://unfccc.int/es/kyoto_protocol

UNFCCC. (2015). Paris Agreement. December 12th 2015. United Nations Framework Convention on Climate Change. Retrieved from https://unfccc.int/es/process-and-meetings/the-paris-agreement/elacuerdo-de-paris

Vadén, T., Lähde, V., Majava, A., Järvensivu, P., Toivanen, T., Hakala, E., \& Eronen, J. T. (2020). Decoupling for ecological sustainability: A categorisation and review of research literature. Environmental Science E Policy, 112, 236-244. https://doi.org/10.1016/j.envsci.2020.06.016

Valero, A., Valero, A., Calvo, G., \& Ortegoa, A. (2018). Material bottlenecks in the future development of green technologies. Renewable and Sustainable Energy Reviews, 93, 178-200. https://doi.org/10.1016/j. rser.2018.05.041

Valladares, F., Magro, S., \& Martín-Forés, I. (2019). Anthropocene, the challenge for "Homo sapiens" to set its own limits. Cuadernos de Investigación Geográfica, 45(1), 33-59. https://doi.org/10.18172/ cig. 3681

van der Sluijs, J. P., van Est, R., \& Riphagen, M. (2010). Beyond consensus: reflections from a democratic perspective on the interaction between climate politics and science. Current Opinion in Environmental Sustainability, 2, 409-415. https://doi.org/10.1016/j.cosust.2010.10.003

Verdnasky, V. [1997(1926)]. La Biosfera. Madrid: Fundación Argentaria-Visor Dis., Colección Economía y Naturaleza. Recuperado de https://fcmanrique.org/fcm-publicacion/la-biosfera-2/?cpg=3\&lang=es

Wamsler, C., Schäpke, N., Fraude, C., Stasiak, D., Bruhn, T., Lawrence, M., ... Mundaca, L. (2020). Enabling new mindsets and transformative skills for negotiating and activating climate action: Lessons from UNFCCC conferences of the parties. Environmental Science \& Policy, 112, 227-235. https://doi.org/10.1016/j.envsci.2020.06.005 
Ward, J. D., Sutton, P. C., Werner, A. D., Costanza, R., Mohr, S. H., \& Simmons, C. T. (2016). Is Decoupling GDP Growth from Environmental Impact Possible?. PLOS ONE, 11(10), e0164733. https://doi. org/10.1371/journal.pone.0164733

WCED (World Commission on Environment and Development ). (1987). Our common future. Oxford: Oxford University Press.

Weart, S. R. (2008). The discovery of global warming. Cambridge, Massachusetts: Harvard University Press (revised and expanded edition).

Wiedenhofer, D., Virág, D., Kalt, G., Plank, B., Streeck, J., Pichler, M., .. Haberl, H. (2020). A systematic review of the evidence on decoupling of GDP, resource use and GHG emissions, part I: bibliometric and conceptual mapping. Environmental Research Letters, 15(6), 063002. https://doi.org/10.1088/17489326/ab8429

Wiedmann, T., Lenzen, M., Keyßer, L. T., \& Steinberger, J. K. (2020). Scientists' warning on affluence. Nature Communications, 11(3107), 1-10. https://doi.org/10.1038/s41467-020-16941-y

Wilson, C. L., \& Matthews, W. H. (1971). Inadvertent climate modification: Report of the Conference, Study of Man's Impact on Climate. Cambridge, Massachusetts.

WMO (World Meteorological Organization). (1979). Proceedings of the world climate conference: A conference of experts on climate and mankin. Geneva, Switzerland, 12-23 February 1979: World Meteorological Organization No 537.

WMO (World Meteorological Organization). (1988). World Conference on The Changing Atmosphere. Implications for Global Security (Toronto Conference). Geneva, Switzerland: World Meteorological Organization. No. 710.

WMO (World Meteorological Organization). (1990). Second World Climate Conference. Conference statement. Geneva, Switzerland.

WMO (World Meteorological Organization). (2009a). World Climate Conference-3. Conference Statement. Summary of the Expert Segment. 31 August - 4 September 2009. Geneva, Switzerland.

WMO (World Meteorological Organization). (2009b). World Climate Conference-3. Global Framework for Climate Services. Brief Note. 31 August-4 September 2009. Geneva, Switzerland.

Zelli, F., \& van Asselt, H. (2010). The overlap between the UN climate regime and the World Trade Organization. In F. Biermann, P. Pattberg, \& F. Zelli (Eds.), Global Climate Governance Beyond 2012 (pp. 79-96). Cambridge: Cambridge University Press. https://doi.org/10.1017/ CBO9781139107150.008

Zillman, J. W. (2009). A history of climate activities. WMO Bulletin, 58(3), 141-150. 